\title{
Cognitive intelligence, emotional intelligence and personality types as predictors of job performance: Exploring a model for personnel selection
}

\begin{tabular}{|c|c|}
\hline \multicolumn{2}{|c|}{$\begin{array}{l}\text { Authors: } \\
\text { Pfungwa Dhliwayo }^{1} \text { (D) } \\
\text { Melinde Coetzee }^{1} \text { (D) }\end{array}$} \\
\hline \multicolumn{2}{|c|}{$\begin{array}{l}\text { Affiliations: } \\
{ }^{1} \text { Department of Industrial } \\
\text { and Organisational } \\
\text { Psychology, College of } \\
\text { Economic and Management } \\
\text { Sciences, University of South } \\
\text { Africa, Pretoria, South Africa }\end{array}$} \\
\hline \multicolumn{2}{|c|}{$\begin{array}{l}\text { Corresponding author: } \\
\text { Melinde Coetzee, } \\
\text { coetzm1@unisa.ac.za }\end{array}$} \\
\hline \multicolumn{2}{|c|}{$\begin{array}{l}\text { Dates: } \\
\text { Received: } 27 \text { Feb. } 2020 \\
\text { Accepted: } 18 \text { Aug. } 2020 \\
\text { Published: } 26 \text { Oct. } 2020\end{array}$} \\
\hline \multicolumn{2}{|c|}{$\begin{array}{l}\text { How to cite this article: } \\
\text { Dhliwayo, P., \& Coetzee, M. } \\
\text { (2020). Cognitive intelligence, } \\
\text { emotional intelligence and } \\
\text { personality types as } \\
\text { predictors of job } \\
\text { performance: Exploring a } \\
\text { model for personnel } \\
\text { selection. SA Journal of } \\
\text { Human Resource } \\
\text { Management/SA Tydskrif } \\
\text { vir Menslikehulpbronbestuur, } \\
\text { 18(0), a1348. https://doi. } \\
\text { org/10.4102/sajhrm. } \\
\text { v18i0.1348 }\end{array}$} \\
\hline \multicolumn{2}{|c|}{$\begin{array}{l}\text { Copyright: } \\
\text { (C) 2020. The Authors. } \\
\text { Licensee: AOSIS. This } \\
\text { is licensed under the } \\
\text { Creative Commons } \\
\text { Attribution License. }\end{array}$} \\
\hline \multicolumn{2}{|l|}{ Read online: } \\
\hline 口:pra & $\begin{array}{l}\text { Scan this QR } \\
\text { code with your } \\
\text { smart phone or } \\
\text { mobile device } \\
\text { to read online. }\end{array}$ \\
\hline
\end{tabular}

Orientation: The process of personnel selection is essential for organisations because it ensures that only those candidates who are likely to contribute to the economic value of an organisation are chosen to fill job vacancies.

Research purpose: This research sought to explore cognitive intelligence (CI), ability emotional intelligence (ability EI), trait emotional intelligence (trait EI) and personality types as predictors of job performance with the view to propose a valid selection model for the Zimbabwean organisational context.

Motivation for the study: In the personnel selection context, separate studies investigated the single predictive power of the constructs relevant to the study in different settings and studies. The role of personality types in selection is especially under-researched.

Research approach, design and method: The study utilised a cross-sectional survey design. The convenience sample constituted $(N=299)$ supervisory and professionally qualified, experienced specialists from various organisations in Zimbabwe. The GAMA, AES, WEIS, MBTI, Form M and JPS were administered.

Main findings: Structural equation modelling indicated CI as the best predictor of job performance, followed by ability EI and then by personality types. Trait EI could not account for any variance in job performance.

Practical implications/managerial implications: Personnel selection models in the Zimbabwean context could consider including the empirically demonstrated variables in selection practices.

Contribution/value-add: The research advanced personnel selection theory by empirically and scientifically identifying the core elements of, and proposing a personnel selection model for use by human resources practitioners and organisations in the African context.

Keywords: cognitive intelligence; ability emotional intelligence; trait emotional intelligence; personality type; personnel selection; job performance; organisational citizenship behaviour; task performance; emotional labour.

\section{Introduction}

The process of personnel selection is essential for organisations because it ensures that only the candidates who can contribute to the economic value of an organisation are chosen to fill job vacancies (Afshari, Nikolić, \& Ćoćkalo, 2014; Caldwell, Beverage, \& Converse, 2018). In filling job vacancies, organisations use a variety of personnel selection methods and measures to ensure the best person-job fit (Joseph \& Newman, 2010). The present study, thus, sought to explore a personnel selection model that could be applied with confidence in the Zimbabwean and perhaps African organisational context. The practical utility of the study stems from employment malpractices, high labour turnover and brain drain that existed and still exist in the Zimbabwean business sector from about 1998 to the present, as the country is characterised by economic recession (Dumbu \& Chadamoyo, 2012; Nguwi, 2014b; Nyamubarwa, Mupani, \& Chiduuro, 2013; Zinyemba, 2014). Thus, exploring a scientific valid personnel selection model is expected to assist organisations to still employ suitable people despite the aforementioned problems.

The present study explored the constructs of cognitive intelligence (CI), ability emotional intelligence (ability EI), trait emotional intelligence (trait EI) and personality types as 
predictors of job performance. Although the constructs of $\mathrm{CI}$, ability EI, trait EI, personality and job performance are well known for their usefulness in personnel selection, there is a lack of research that studies these constructs jointly in a single study. Prior studies, for example separate researches conducted by Abraham (2004), AlDosirya, Alkhadher, AlAqraa and Anderson (2016), Cote and Miners (2006), Lam and Kirby (2002), McNulty, Mackay, Lewis, Lane and White (2016), Murensky (2000), Sony and Mekoth (2016), Tofighi, Tirgari, Fooladvandi, Rasouli and Jalal (2015), Wolff, Pescosolido and Druskat (2002) and Wong and Law (2002), explored the influence of either one or two of the predictor variables (CI, EI and personality) on job performance. The separate studies present a gap in research because it may be difficult to compare the predictive power of the different constructs in a valid and reliable manner. Even though Joseph and Newman (2010) and O'Boyle, Humphrey, Pollack, Hawver and Story (2011) used meta-analyses to investigate the predictive power of the aforementioned predictor variables on job performance, the meta-analyses still have the same methodological drawbacks of reaching conclusions using separate studies.

\section{Research purpose and objective}

This research sought to explore CI, ability EI, trait EI and personality types as predictors of job performance with the view to propose a valid personnel selection model for the Zimbabwean organisational context. Several studies investigated the single predictive power of these different constructs in the personnel selection context. Moreover, the role of personality types in selection is especially underresearched. Understanding the different predictive powers of the variables jointly in terms of job performance may help to construct an integrated personnel selection model that may help improve selection practices.

The predictor variables of CI, and ability EI and trait EI are relevant to the study because research proved them to be theoretically valid and distinct constructs (Joseph \& Newman, 2010; O'Boyle et al., 2011). Personality type (Myers, 1987) is under-researched in the personnel selection context. Although the trait factor theories, for example, the five factor model (Costa \& McCrae, 1992), have been extensively tested in personnel selection contexts, other personality theories such as the psychodynamic, social learning, humanistic and dispositional theories have been found to be less applicable to personnel selection contexts (Feist \& Feist, 2009; Myers, McCaulley, Quenk, \& Hammer, 1998). Even though the personality type theory is applicable to occupational settings, it has been mainly used for personnel development (Chen, Tian, Miao, \& Chia, 2009; Leary, Reilly, \& Brown, 2009; Myers et al., 1998) and may therefore need to be tested in personnel selection contexts. Assessing the fidelity of personality types in combination with the constructs of $\mathrm{CI}$, ability EI and trait EI and in relation to job performance from a selection predictive point of view would assist organisations to identify employee development needs at the personnel selection stage.

\section{Literature review}

This section reviews the literature on personnel selection models, personnel selection practices in Zimbabwe and the concepts of job performance, CI, EI and personality types. The section also reviews the literature on the association between the variables relevant to the study and ends by stating the research hypothesis.

\section{Models of personnel selection}

Human resources (HR) practitioners and industrial psychologists normally use a combination of personnel selection methods and measures, and this combination constitutes a personnel selection model (Ployhart \& Schneider, 2012). There are a number of personnel selection methods, which include application forms, graphology, reference checks, job knowledge tests and the selection interview, most of which have been found to have low validity in predicting job performance (Dale, 2003; Gatewood, Feild, \& Barrick, 2016; Motowidlo, 2003; Schmidt \& Hunter, 1998). On the contrary, there are psychological personnel selection measures such as CI, EI, personality and assessment centres, which are more scientific with better predictive validity (Anastasi \& Urbina, 1997; Cote \& Miners, 2006; Gregory, 2004; Hunter \& Hunter, 1984; Joseph \& Newman, 2010; O’Boyle et al., 2011).

Personnel selection involves the use of multiple methods and measures to be able to predict the multi-nature of the job performance criteria (Ployhart \& Schneider, 2012). The underlying assumption of personnel selection models is that, as personnel selection measures are added to the model, the predictive validity is improved by way of incremental validity (Hattrup, 2012). Certain criteria must therefore characterise personnel selection models for them to predict job performance with fidelity. For example, each of the personnel selection methods or measures constituting a personnel selection model should be able to predict job performance at significant levels (Joseph \& Newman, 2010). In addition, each personnel selection method or measure should be theoretically distinct from the constructs represented by other personnel selection methods or measures in the model to avoid redundancy (Joseph \& Newman, 2010).

From our review of the literature, we classified personnel selection models into two major categories. First, there are models whose objective is to automate the decision-making processes such as resume screening (Kaluginaa \& Shvyduna, 2014; Shehu \& Saeed, 2016). We labelled these models 'efficiency personnel selection models'. Efficiency-based personnel selection models suffer the drawback of being silent on the predictive power of the models, which is an important aspect of personnel selection. The second group consists of models that use regression techniques to determine the predictive power of different personnel selection measures and methods (Joseph \& Newman, 2010; O'Boyle et al., 2011; Ployhart \& Schneider, 2012). We termed these 
models 'predictive personnel selection models'. The proposed personnel selection model for our research was, thus, predictive in nature.

\section{Personnel selection practices in Zimbabwean organisations}

Nguwi (2014a) states that many organisations in Zimbabwe still depend on the traditional personnel selection methods, which include the review of professional resumes and the selection interview. This is despite the fact that research has already established the ineffectiveness of the aforementioned practices (Nguwi, 2010). Nguwi (2010) also points out that the pitfalls of personnel selection methods such as the unstructured interviews emanate from the subjectivity of the judgements and conclusion arrived at because of the lack of standardisation of the interview process, which results in biases. In addition, most organisations in Zimbabwe engage in nepotism by employing their relatives and use unscientific personnel selection measures and methods (Dumbu \& Chadamoyo, 2012; Nyamubarwa et al., 2013, Zinyemba, 2014). Thus, if Zimbabwean organisations fail to adopt valid personnel selection models, they may continue to employ unsuitable people, resulting in reduced employee performance capability. The study therefore sought to propose a scientific and valid model for personnel selection.

\section{Job performance}

Job performance refers to the engagement in behaviour aimed at achieving tasks and duties that contribute to the economic value of an organisation (Bozionelos \& Singh, 2017; Dan, Zhang, \& Li, 2015; Motowidlo, 2003; Rich, Lepine, \& Crawford, 2010). Job performance encapsulates both results and behaviour. The results-based approach represents the outcome of job performance (Rich et al., 2010). On the contrary, the behavioural approach to job performance is based on the notion that the behaviour is observable and provides a medium through which organisational results can be achieved (Jundt, Shoss, \& Huang, 2014; Motowidlo, 2003; Tufail, Bashi, \& Shoukat, 2017). Motowidlo (2003) argues that defining job performance from a behavioural point of view assists industrial psychologists to develop measures to assess how the results are achieved. Thus, although the ultimate outcome of job performance (results) is the evidence of job performance, the behaviour engaged in by employees may also be important in explaining how the results were achieved, leading to the notion that job performance is a multi-factor criterion (Williams \& Anderson, 1991).

In the present study, job performance is conceptualised according to the multi-factor model and in terms of two main domains, namely task and contextual performance (Bozionelos \& Singh, 2017; Williams \& Anderson, 1991). Task performance or in-role behaviour refers to the effectiveness in performing activities that contribute to the organisation's technical core tasks and focusses on core production activities (Borman \& Motowidlo, 1993; Bozionelos
\& Singh, 2017; Jiao \& Hardie, 2009; Miao, Humphrey, \& Qian, 2017; Varela, Salgado, \& Lasio, 2010; Williams \& Anderson, 1991). The term contextual performance, or organisational citizenship behaviour, refers to extra-role behaviours that contribute to organisational performance because they positively affect the psychological, social and organisational contexts of work (Jiao \& Hardie, 2009; Matula \& Uon, 2016; Motowidlo, 2003). According to Motowidlo (2003), contextual performance may take at least two forms: organisation citizenship behaviour directed towards the organisation (OCBO) and organisation citizenship behaviour directed towards other individuals (OCBI). Organisation citizenship behaviour directed towards the organisation refers to individual effort aimed at assisting the organisation to achieve its objectives, and thus indirectly contributing to the economic value of the organisation (Bozionelos \& Singh, 2017; Motowidlo, 2003; Williams \& Anderson, 1991). Organisation citizenship behaviour directed towards other individuals occurs when individuals engage in behaviours that result in the improvement of their work colleagues' job performance, for example assisting them with job tasks (Borman \& Motowidlo, 1993; Bozionelos \& Singh, 2017; Williams \& Anderson, 1991).

\section{Cognitive intelligence}

The concept of CI refers to the ability to think rationally and to solve factual, novel and complex problems and is regarded as a major determinant for the survival of species (Gottfredson, 1997; Jensen, 1998; Lam \& Kirby, 2002; Rindermann, 2007). Gregory (2004) conceptualises CI as the ability to reason (acquiring knowledge and using it for future purposes), to learn and to adapt to one's environment. Spearman (1923) demonstrated that an individual's performance on a variety of CI tests or subtests of intellectual effectiveness was determined by the general factor $(g)$ and another factor $(s)$ specific to the test or subtests (Willis, Dumont, \& Kaufman, 2011). According to Spearman $(1923,1927 a)$, performance on the subtests of CI was not influenced by a single specific factor (s), meaning that the more pervasive $g$ was responsible for the performance (Floyd, McGrew, Barry, Raphael, \& Rodgers, 2009; Willis et al., 2011). Gregory (2004) argues that the $g$ supports the $s$ by way of providing a common supply of mental energy as and when it is needed. Theories proposed by Thurstone (1938), Vernon (1950), Sternberg's (1985), Gardner (1983, 1993, 1999), Guilford (1967) and Cattell (1941, 1971) support Spearman's (1904, 1923, 1927a) $g$ and $s$. Specifically, most of the theories acknowledge the presence of a $g$ of CI that is pervasive and assists people to adapt to their environments. For this reason, we conceptualised CI as a unitary concept represented as general mental ability in line with Spearman (1904, 1923, 1927a).

\section{Emotional intelligence}

The concept of EI has attracted attention over the last three decades (Gooty, Gavin, Ashkanasy, \& Thomas, 2014; Joseph \& Newman, 2010; O’Boyle et al., 2011; Wu, 2011). The 
emergence of the EI theory arose because of the realisation that CI alone could not explain all antecedence of job performance and occupational outcomes (Joseph \& Newman, 2010; O'Boyle et al., 2011). Thus, the EI theory was developed mainly to explain the importance of non-cognitive components of intelligence to occupational outcomes including job performance (Murphy \& Janeke, 2010).

Murphy and Janeke (2010) conceptualise EI as individuals' traits or skills that help them to adapt to the environment by interpreting, managing and using theirs and others' emotions to solve problems. Some researchers such as Mayer, Salovey and Caruso (2000) define EI as an ability to process emotional information cognitively, whereas others such as Schutte, Malouff and Bhullar (2009) and Schutte et al. (1998) argue that EI is a dispositional trait. The foregoing discourse resulted in two divergent conceptualisations of EI, that is EI as an ability and EI as a trait.

\section{Ability emotional intelligence}

The conceptualisation of EI as an ability is based on the premise that EI is a set of cognitive abilities required for the processing of emotional information and the regulation of emotions (Mayer \& Salovey, 1997; Wong, Law, \& Wong, 2004; Wong, Wong, \& Law, 2007; Zeidner, Matthews, \& Roberts, 2004). The main difference between ability EI and other types of EI is that ability EI test items require the choice of a correct answer (Mayer et al., 2000). Mayer et al. (2000) conceptualise EI in terms of the four branches, namely identification, understanding, usage and regulation of emotions. Although ability EI is divided into the four-branch model, it is, however, unitary in nature, just like CI (Mayer \& Salovey, 1997; Mayer, Salovey, \& Caruso, 2004; Wong et al., 2004).

\section{Trait emotional intelligence}

Petrides, Pita and Kokkinaki (2007) define trait EI as a collection of emotion-related dispositions that can be assessed through self-reports. Although theorists may vary in terms of its conceptualisation, trait EI can generally be described in terms of four factors, namely perception of emotion, managing own emotions, managing others' emotions and utilisation of emotion (Schutte et al., 2009). In contrast to ability EI, the definition of trait EI is straightforward because it is a non-cognitive affective construct and acknowledges that emotions are subjective (Petrides et al., 2007). Petrides and Furnham (2003) argue that the conceptualisation of trait $\mathrm{EI}$ is robust because the construct is distinct from CI and personality.

\section{Personality type}

The theory of psychological type (Jung, 1921) underpins the personality type theory of Myers and Briggs (Myers, 1987). The concept of psychological types was developed from a combination of the two attitudes (extraversion and introversion) and the four psychological functions (thinking, feeling, intuiting and sensing) (Burger, 2014; Feist \& Feist, 2009). Myers and Briggs (Myers, 1987) extended Jung's (1921) theory by adding an auxiliary function (judging and perceiving) and the auxiliary function's balancing role in extraversion and introversion (Kirby \& Myers, 2000). The personality type theory, thus, consists of two attitudes and six psychological functions (Myers, 1987). The attitudes and functions can be classified into four dichotomies and these are extraversion (E) versus introversion $(\mathrm{I})$, sensing $(\mathrm{S})$ versus intuition $(\mathrm{N})$, thinking $(\mathrm{T})$ versus feeling $(\mathrm{F})$ and judging $(\mathrm{J})$ versus perceiving (P) (Kirby \& Myers, 2000). The four dichotomies produce 16 personality types, which describe personality in terms of a four-letter code (e.g. ENFP) and described in more detail by Kirby and Myers (2000). According to Myers (1987), the four dichotomies do not develop as balanced because this would result in undifferentiated personality. Rather, one of the four dichotomies becomes dominant, giving direction to differentiated personality (McCaulley \& Martin, 1985, Myers, 1987).

\section{Associations between the constructs}

Weak correlations have been found between ability EI and trait EI (Brackett \& Mayer, 2003; Goldenberg, Matheson, \& Mantler, 2006; Mayer, Salovey, \& Caruso, 2002). Low correlations have also been reported between ability EI and personality (Austin, Farrelly, Black, \& Moore, 2007; Joseph \& Newman, 2010). With regard to CI, correlations between ability EI and CI have been found to be moderate to high (Austin, 2010; Cote \& Miners, 2006; Joseph \& Newman, 2010). In terms of job performance, Gooty et al. (2014) found that ability EI was related to task performance. Greenidge, Devonish and Alleyne (2014) found that the four dimensions of ability EI were positively correlated with organisational citizenship behaviour. A study by Sony and Mekoth (2016) shows that ability EI is positively correlated with job performance. Fallon et al. (2014) found ability EI to be a predictor of job performance through better decision-making. However, meta-analysis has revealed that in predicting job performance, ability EI measures have very low incremental validity beyond CI (O'Boyle et al., 2011).

Concerning the relationship between trait EI and personality type as measured by the Myers-Briggs Type Indicator (MBTI), significant positive correlations have been found between trait EI and sensing-intuition, thinking-feeling and extraversion-introversion (Higgs, 2001; Leary et al., 2009). Meta-analyses conducted by Joseph and Newman (2010) and O'Boyle et al. (2011) reveal weak relationships between trait EI and CI as well as ability EI. Research also provides evidence for trait EI from both explanatory and predictive viewpoints (Hui-Hua \& Schutte, 2015; Mikolajczak, Roy, Verstrynge, \& Luminet, 2009). For example, Wu (2011) found that trait EI significantly predicts job performance. Jung and Yoon (2012) found trait EI to predict organisational citizenship behaviour at significant levels. Joseph and Newman's (2010) and O'Boyle et al.'s (2011) meta-analyses 
revealed that trait EI has incremental validity beyond personality better than ability EI. Schutte et al. (1998) note that people with high trait EI tend to perform better on difficult and frustrating tasks than those low on trait EI. Trait EI has also been found to predict job performance better in high emotional than in low emotional labour jobs (Joseph \& Newman, 2010; O’Boyle et al., 2011).

Perry and Ball (2005) found a significant correlation between intrapersonal and interpersonal intelligence and the MBTI personality types, with no significant relationship with trait EI. This seems to indicate that personality types and trait EI are two distinct constructs. A study by Virmozelova and Dimitrova (2013) revealed that sensing and introversion were negatively correlated with sharing emotions and empathy and optimism, whereas extraversion correlated positively with sharing emotions and empathy. Johnson and Miller (2003) showed that extraversion is significantly positively correlated with the total EI score as measured by the Global Personality Inventory of Schmit, Kihm and Robie (2000), as well as the subscales of self-awareness, social skills, motivation and empathy. Johnson and Miller (2003) also found a low-to-moderate negative correlation between MBTI intuition and the total Global Personality Inventory as well as on all the subscales. The observed negative and low correlation between the personality types and the rest of the Global Personality Inventory EI scales suggests that trait EI and MBTI conceptualisation of personality may be, to a larger extent, distinct constructs. It is therefore worth investigating the MBTI in personnel selection contexts as it may have incremental validity in a personnel selection model.

Furnham, Dissou, Sloan and Chamorro-Premuzic (2007) note that studies on the relationship between personality types and CI are very few. Furnham et al. (2007) demonstrated that personality as measured by the MBTI showed that intuition and perceiving scores were positively and moderately correlated with both fluid and crystallised intelligence. This seems to be consistent with an earlier study by Kaufman, McLean and Lincoln (1996) in which individuals with high scores on intuition tended to score higher on CI. Myers and McCaulley (1985) also found intuitive individuals to have higher CI. One would, therefore, argue that if some personality types are correlated with other psychological constructs relevant to occupational settings, then it is worth testing the personality type theory in personnel selection contexts.

Research on the relationship between personality types and job performance is limited (Feist \& Feist, 2009). Vincent, Ward and Denson (2013) found that the MBTI's intuition is associated with leadership performance. The MBTI types have also been found to improve the quality of decision-making and problem solving (Prince, 2015; Sample, 2017), which is expected to lead to a better job performance. Engineers high on judging and intuition were found to perform better on the job (Carr, De la Garza, \& Vorster, 2002). Because the area of personality types and job performance seems under-researched, more research is needed to determine the utility of personality types in personnel selection. Concerning the predictive power of CI, there is ubiquitous evidence, suggesting that CI predicts job performance across most, if not all, occupations (Cote \& Miners, 2006; Gottfredson, 1997; Jensen, 1998; Joseph \& Newman, 2010; Lam \& Kirby, 2002; O’Boyle et al., 2011; Rindermann, 2007).

Based on a review of the research literature, the following research hypothesis was formulated:

H1: Cognitive intelligence, ability EI, trait EI and personality type significantly predict job performance.

\section{Methods}

This section describes the research methodology in terms of the research design, the research participants, the measuring instruments, the research procedure, ethical considerations and data analysis.

\section{Research design}

The study was exploratory in nature and utilised a crosssectional survey design (Leavy, 2017). The joint predictive power of $\mathrm{CI}$, ability EI, trait EI and personality types in terms of job performance is not well understood and an underresearched phenomenon.

\section{Participants}

The research participants consisted of a convenient sample $(N=299)$ of supervisory-level employees and professionally qualified and experienced specialists from five private and publicly listed organisations in Zimbabwe. Black African males (61.2\%) and females (38.8\%) represented the sample. Almost half of the participants had more than 10 years' tenure $(49.5 \%)$ and the other half had less than 10 years' tenure $(50.5 \%)$. The $22-36$ years age group $(60.5 \%)$ was predominant in the sample. Thus, a relatively young workforce of experienced and qualified specialists formed a majority of the sample.

\section{Measuring instruments}

\section{Cognitive intelligence}

The construct was measured by means of the General Ability Measure for Adults (GAMA; Naglieri \& Bardos, 1997). The GAMA has 66 items and four subscales (matching, analogies, sequences and construction) and has proven reliability and validity (Davis, Bardos, \& Woodward, 2006; Naglieri \& Bardos, 1997).

\section{Ability emotional intelligence}

Wong's Emotional Intelligence Scale (WEIS; Wong et al., 2004) was administered. The WEIS is a forced-choice measure, designed to measure EI along four subscales (selfemotional appraisal, other's emotional appraisal, use of emotion and regulation of emotion). The WEIS consists of 40 items (20 pairs of abilities and 20 scenarios). The WEIS is parsimonious and has proven reliability and validity (Foo, 
Elfenbein, Tan, \& Aik, 2004; Husina, Santos, Ramosa, \& Nordinb, 2013; Wong et al., 2004; Wong et al., 2007).

\section{Trait emotional intelligence}

The Assessing Emotions Scale (AES; Schutte et al., 1998) was utilised. Emotional intelligence is measured along four subscales (perception of emotion, managing own emotions, managing others' emotions and utilisation of emotion). The AES consists of 33 items and the responses are recorded on a five-point scale ranging from 1 (strongly disagree) to 5 (strongly agree). The AES has proven reliability and validity (Bastian, Bums, \& Nettelbeck, 2005; Brackett \& Mayer, 2003; Schutte et al., 1998; Schutte et al., 2009).

\section{Personality type}

The MBTI Form M (Myers et al., 1998) was administered. The MBTI Form M is a self-report personality measure. The scale consists of 93 items and the responses are interpreted along four bipolar scales which are extraversionintroversion $(E / I)$, sensing-intuition $(S / N)$, thinkingfeeling $(\mathrm{T} / \mathrm{F})$ and judging-perceiving $(\mathrm{J} / \mathrm{P})$. These four bipolar categories were utilised in the statistical analyses as categorical data. The MBTI Form $\mathrm{M}$ has demonstrable reliability and validity (Myers et al., 1998, Myers \& Myers, 2009; Tabachnick \& Fidell, 2001).

\section{Job performance}

The Job Performance Scale (JPS) of Williams and Anderson (1991) was administered. The scale measures job performance through supervisory ratings along three subscales (OCBI, $\mathrm{OCBO}$ and in-role behaviours [task performance]). The scale consists of 21 items, with seven items in each of the three subscales. Responses are recorded on a five-point scale ranging from 1 (strongly disagree) to 5 (strongly agree). The scale has good reliability and validity (Organ, Podsakoff, \& MacKenzie, 2006; Williams \& Anderson, 1991).

\section{Procedure}

The primary researcher, a registered industrial or occupational psychologist with the Allied Health Practitioners Council of Zimbabwe, collected the data by means of scheduled contact sessions of at most 20 people, with participants completing the four measuring instruments. The JPS was also emailed to participants' supervisors, for them to provide information on the participants' performance levels. The researcher recruited participants via an email message.

\section{Data analysis}

The data were statistically analysed by using IBMSPSS version 22 (IBM, 2013) and the SAS version 9.4 (SAS, 2013) software programs. A Harman's single-factor test and confirmatory factor analysis (CFA one-factor solution) was conducted to test for common method variance (CMV) (Tehseen, Ramayah, \& Sajilan, 2017). Cronbach's alpha coefficients and composite reliability were computed for each scale. Descriptive statistics, bivariate correlations, CFA and structural equation modelling
(SEM) were performed. Best fit indices included the root means square error of approximation (RMSEA) and standardised root mean residual (SRMR) of below $<0.08$, and the comparative fit index (CFI) above $>0.90$. The MBTI personality types were treated as categorical data: E/I, S/N, $\mathrm{T} / \mathrm{F}$ and $\mathrm{J} / \mathrm{P}$ in the statistical analyses.

\section{Ethical consideration}

Permission to conduct the research was obtained from the participating organisations. The research institution (University of South Africa) also granted ethics clearance. Voluntary participation was honoured, and informed consent to utilise the data for research purposes was obtained from the participants. Confidentiality and anonymity were respected and maintained.

This article followed all ethical standards for carrying out research without direct contact with human or animal subjects.

\section{Results}

\section{Testing for common method variance}

The Harman's one factor test revealed a lack of CMV for the AES (8.59\%), JPS (5.53\%), MBTI (9.16\%) and the WEIS (3.47\%). The one-factor CFAs (see Table 1) for these scales also indicated poor data fit which provided additional evidence that CMV was not a serious threat to the interpretation of the findings. The GAMA was excluded because it was a timed test and as a result had a number of missing responses.

\section{Validity of the measurement model}

SAS version 9.4 (SAS, 2013) was used to test the discriminant validity of the overall measurement model. Discriminant

\begin{tabular}{|c|c|c|}
\hline $\begin{array}{l}\text { Measurement } \\
\text { instrument }\end{array}$ & $\begin{array}{l}\text { Harman's one-factor test: } \\
\text { Percentage variance explained } \\
\text { by a single factor }\end{array}$ & $\begin{array}{l}\text { One-factor solution } \\
\text { (confirmatory factor } \\
\text { analysis) }\end{array}$ \\
\hline \multirow[t]{4}{*}{$\begin{array}{l}\text { Assessing Emotions } \\
\text { Scale }\end{array}$} & \multirow[t]{4}{*}{$8.59 \%$} & $\begin{array}{l}\text { Chi-square }=1043.37 * * * / \\
d f=428\end{array}$ \\
\hline & & SRMR $=0.06$ \\
\hline & & RMSEA $=0.07$ \\
\hline & & $\mathrm{CFI}=0.78$ \\
\hline \multirow[t]{4}{*}{$\begin{array}{l}\text { Job Performance } \\
\text { Scale }\end{array}$} & \multirow[t]{4}{*}{$5.53 \%$} & $\begin{array}{l}\text { Chi-square }=424.36 * * * / \\
d f=186\end{array}$ \\
\hline & & SRMR $=0.06$ \\
\hline & & RMSEA $=0.07$ \\
\hline & & $\mathrm{CFI}=0.86$ \\
\hline \multirow[t]{4}{*}{$\begin{array}{l}\text { Myers-Brigs Type } \\
\text { Indicator }\end{array}$} & \multirow[t]{4}{*}{$9.16 \%$} & $\begin{array}{l}\text { Chi-square }=/ d f= \\
12170.18^{* * *} / d f=4185\end{array}$ \\
\hline & & SRMR $=0.11$ \\
\hline & & RMSEA $=0.08$ \\
\hline & & $\mathrm{CFI}=0.20$ \\
\hline \multirow{4}{*}{$\begin{array}{l}\text { Wong's Emotional } \\
\text { Intelligence Test }\end{array}$} & \multirow[t]{4}{*}{$3.47 \%$} & Chi-square $=9.14^{* *} / d f=2$ \\
\hline & & SRMR $=0.04$ \\
\hline & & RMSEA $=0.11$ \\
\hline & & $\mathrm{CFI}=0.31$ \\
\hline
\end{tabular}

SRMR, standardised root mean residual; $\mathrm{CFI}$, comparative fit index; RMSEA, root means square error of approximation; $\mathrm{df}$, degrees of freedom. Note: $N=299 ; * * *, p \leq 0.001 ; * *, p \leq 0.01 ; *, p \leq 0.05$. 
validity is important to assess for the presence of multicollinearity among the constructs. Three models (one factor solution, multi-factor solution and optimised multi-factor solution) were run as part of efforts to ascertain the validity of the measurement model. The optimised multi-factor CFA model (see Model 3 in Table 2) showed good model fit (i.e. lack of multi-collinearity) and as such provided evidence of discriminant validity among the various scales' constructs: chi-square $=318.99 / d f=213$; chi-square $/ d f=1.50 ; p \leq 0.001$; RMSEA $=0.05 ;$ SRMR $=0.07 ; \mathrm{CFI}=0.90$ ). We used the CALIS statistical procedure with a maximum likelihood (LevenbergMarquardt optimisation method) to optimise the model fit. Confirmatory factor analysis was not performed for the MBTI because the scale has dichotomous subscales. The absence of multicollinearity shows that the predictor constructs were theoretically distinct and thus satisfied the criteria for a personnel selection model (Hattrup, 2012; Joseph \& Newman, 2010).

\section{Descriptive statistics and internal consistency reliability}

Table 3 shows the means and standard deviations and internal consistency reliability coefficients of the scales. The AES, JPS, GAMA and WEIS had some of their subscales reliabilities below 0.70, which is the cut-off point for good internal consistency reliability (Costa, Van, Abbott, \& Krass, 2015). For the overall scales reliabilities, only the WEIS had the Cronbach's alpha of below 0.70 (0.55). Internal consistency reliability coefficients of $\geq 0.50$ can, however, be acceptable for research purposes (Taber, 2017). The alpha for the overall WEIS scores did not pose a serious threat to the interpretation of the results, but the low alpha was considered in the interpretation of the results.

\section{Bivariate correlations of the dependent and predictor variables}

The MBTI scores were categorical, meaning that the bivariate correlations for the dependent and independent variables had to be computed by using non-parametric tests. The Spearman's correlation (SAS version 9.4; SAS, 2013) was therefore performed.

The practical effect sizes for the bivariate correlations were interpreted in line with Rashid, Mondol, Rahman and Noman (2016). In terms of CI and ability EI, a negative correlation $(r=-0.31, p \leq 0.001$; moderate practical effect) was observed between the overall GAMA and WEIS scales. For the CI and personality, positive correlations were observed between the GAMA and sensing-thinking $(r=0.18, p \leq 0.05$; small

TABLE 2: Construct validity of overall measurement model.

\begin{tabular}{|c|c|c|c|c|c|c|c|}
\hline Model & CFA model type & Chi-square & $d f$ & $p$ & RMSEA & SRMR & CFI \\
\hline 1 & One-factor CFA & 1237.84 & 230 & 0.0001 & 0.16 & 0.16 & 0.27 \\
\hline 2 & Multi-factor CFA & 634.70 & 220 & 0.0001 & 0.11 & 0.09 & 0.70 \\
\hline 3 & Optimised multi-factor CFA & 318.99 & 213 & 0.0001 & 0.05 & 0.07 & 0.90 \\
\hline
\end{tabular}

SRMR, standardised root mean residual; CFI, comparative fit index; RMSEA, root means square error of approximation; CFA, confirmatory factor analysis; df, degrees of freedom. Note: $N=299$.

TABLE 3: Descriptive statistics and internal consistency reliability.

\begin{tabular}{|c|c|c|c|c|}
\hline Scales and dimensions & Cronbach's $\alpha$ & Composite reliability & Mean & SD \\
\hline Assessing Emotions Scale & 0.90 & 0.90 & 4.05 & 0.46 \\
\hline Perception of emotion & 0.80 & 0.80 & 3.89 & 0.55 \\
\hline Managing own emotions & 0.78 & 0.78 & 4.13 & 0.54 \\
\hline Managing others' emotions & 0.66 & 0.66 & 4.13 & 0.53 \\
\hline Utilisation of emotion & 0.72 & 0.70 & 4.15 & 0.56 \\
\hline Job Performance Scale & 0.84 & 0.84 & 4.14 & 0.36 \\
\hline OCBI & 0.78 & 0.69 & 3.98 & 0.52 \\
\hline ОСВО & 0.68 & 0.60 & 4.21 & 0.49 \\
\hline Wong's Emotional Intelligence Test & 0.55 & $\mathrm{~N} / \mathrm{A}$ & 28.33 & 3.83 \\
\hline Self-emotional appraisal & 0.16 & - & 7.51 & 1.36 \\
\hline Other's emotional appraisal & 0.19 & - & 6.89 & 1.44 \\
\hline Regulation of emotion & 0.16 & - & 6.62 & 1.39 \\
\hline Use of emotion & 0.17 & - & 7.30 & 1.41 \\
\hline Extraversion-introversion (E/I) & 0.78 & - & - & - \\
\hline Sensing-intuition (S/N) & 0.81 & - & - & - \\
\hline Thinking-feeling (T/F) & 0.84 & - & - & - \\
\hline Judging-perceiving (J/P) & 0.84 & - & - & - \\
\hline General Ability Measure for Adults & 0.76 & N/A & 32.27 & 6.10 \\
\hline Matching & 0.33 & - & 8.67 & 1.37 \\
\hline Analogies & 0.56 & - & 10.02 & 2.46 \\
\hline Sequences & 0.61 & - & 7.33 & 2.39 \\
\hline Construction & 0.40 & - & 6.25 & 1.71 \\
\hline
\end{tabular}

OCBI, organisation citizenship behaviour directed towards other individuals; OCBO, organisation citizenship behaviour directed towards the organisation; SD, standard deviation. 
practical effect) and the GAMA and intuition-thinking ( $r=$ $0.18, p \leq 0.05$; small practical effect). Negative correlations were, however, observed between the GAMA and sensingfeeling ( $r=-0.18, p \leq 0.05$; small practical effect) and the negative GAMA and intuition-feeling $(r=-0.19, p \leq 0.05$; small practical effect). For CI and EI, there were no significant correlations between the overall GAMA and the AES (trait EI) and between the overall WEIS (ability EI) and AES. Concerning ability EI and personality, there were positive correlations between the WEIS and intuition-feeling ( $r=$ 0.17, $p \leq 0.05$; small practical effect) and the WEIS and sensing-feeling ( $r=0.18$; small practical effect, $p \leq 0.05)$. The WEIS was negatively correlated with the sensing-thinking dichotomy ( $r=-0.16, p \leq 0.05$; small practical effect). A significant positive correlation was found between trait EI (AES overall score) and the MBTI intuition-feeling ( $r=0.15$, $p \leq 0.05$; small practical effect). In summary, no correlations between the predictor variables were above $r=0.80$, indicating the absence of multicollinearity and further demonstrating a discriminant validity of the measurement model (Cohen, Cohen, West, \& Aiken, 2013).

The correlation between CI (GAMA) and JPS was significant $(r=0.35, p \leq 0.001$; moderate practical effect). For ability EI (WEIS), the regulation of emotions was the only subscale that had a significant correlation with overall job performance $(r=0.18, p \leq 0.05$; small practical effect $)$ and OCBI $(r=0.23$, $p \leq 0.01$; small practical effect). Trait EI (overall AES) was significantly correlated with only task performance ( $r=0.15$, $p \leq 0.05$; small practical effect), and the perception of emotion subscale was significantly correlated with both overall job performance ( $r=0.15, p \leq 0.05$; small practical effect) and task performance ( $r=0.20, p \leq 0.05$; small practical effect). In terms of personality, there was significant positive correlation between the sensing-thinking dichotomy and overall job performance ( $r=0.15, p \leq 0.05$; small practical effect), showing that the thinking type is significantly correlated with job performance. The results revealed a significant positive correlation between the sensing-feeling dichotomy and OCBO ( $r=-0.15, p \leq 0.05$; small practical effect), demonstrating that the feeling type is negatively correlated with job performance.

\section{Testing the research hypothesis: Structural equation modelling}

SAS version 9.4 (SAS, 2013) was used to perform SEM and path analysis. The CALIS procedure of covariance structure analysis with a maximum likelihood estimation was utilised. The various measures (CI, ability EI, trait EI and job performance) were treated as overall constructs and the MBTI personality types as categorical construct types: E/I, $\mathrm{S} / \mathrm{N}, \mathrm{T} / \mathrm{F}$ and J/P. Four SEM models were run and the results are reported in Table 5 . The four models had good fit statistics

TABLE 4: Bivariate correlations of the dependent and predictor variables.

\begin{tabular}{|c|c|c|c|c|c|c|c|c|c|c|c|c|c|c|}
\hline Variable & GAMA & Matching & Analogies & Sequence & Construction & WEIS & $\begin{array}{c}\text { Self } \\
\text { emotional } \\
\text { appraisal }\end{array}$ & $\begin{array}{l}\text { Others } \\
\text { motional } \\
\text { appraisal }\end{array}$ & $\begin{array}{c}\text { Use } \\
\text { of } \\
\text { emotion }\end{array}$ & $\begin{array}{c}\text { Regulation } \\
\text { of } \\
\text { emotion }\end{array}$ & AES & $\begin{array}{c}\text { Perception } \\
\text { of } \\
\text { emotion }\end{array}$ & $\begin{array}{l}\text { Managing } \\
\text { own } \\
\text { emotion }\end{array}$ & $\begin{array}{l}\text { Managing } \\
\text { others } \\
\text { emotion }\end{array}$ \\
\hline GAMA & - & - & - & - & - & - & - & - & - & - & - & - & - & - \\
\hline Matching & $.63 * * *$ & - & - & - & - & - & - & - & - & - & - & - & - & - \\
\hline Analogies & $.87 * * *$ & $.46 * * *$ & - & - & - & - & - & - & - & - & - & - & - & - \\
\hline Sequence & $.80 * * *$ & $.40 * * *$ & $.56 * * *$ & & - & - & - & - & - & - & - & - & - & - \\
\hline Construction & $.64 * * *$ & $.26 * * *$ & $.49 * * *$ & $.39 * * *$ & - & - & - & - & - & - & - & - & - & - \\
\hline WEIS & $-.31 * * *$ & $-.19 *$ & $-.29 * * *$ & $.21 * * *$ & -.20 & - & - & - & - & - & - & - & - & - \\
\hline Self emotional appraisal & $-.30 * * *$ & $-.25 * * *$ & $.27 * * *$ & $-.20 * *$ & -.11 & $.64 * * *$ & - & - & - & - & - & - & - & - \\
\hline $\begin{array}{l}\text { Others motional } \\
\text { appraisal }\end{array}$ & $-.29 * * *$ & -.14 & $.22 * * *$ & $.26 * * *$ & $-.22 * * *$ & $.62 * * *$ & $.20 * *$ & - & - & - & - & - & - & - \\
\hline Use of emotion & $-.16^{*}$ & .04 & $.22 * * *$ & -.10 & -.13 & $.56 * * *$ & -.12 & $.20 * *$ & - & - & - & - & - & - \\
\hline Regulation of emotion & -.08 & $-.19 * *$ & -.06 & .02 & -.05 & $.61 * * *$ & $.41 * * *$ & -.14 & .07 & - & - & - & - & - \\
\hline AES & .03 & -.08 & .06 & .07 & -.02 & .06 & -.04 & .04 & -.02 & $.18^{* *}$ & - & - & - & - \\
\hline Perception of emotion & 0.12 & 0.02 & 0.11 & 0.12 & 0.05 & 0.09 & 0.02 & -0.04 & 0.06 & $.19 * *$ & $.78 * * *$ & - & - & - \\
\hline Managing own emotion & -.05 & -0.09 & .00 & -0.02 & -0.06 & 0.07 & 0.01 & 0.01 & -0.08 & $.26 * * *$ & $.83 * * *$ & $.49 * * *$ & - & - \\
\hline Managing others emotion & -.00 & -.14 & .02 & .05 & -.01 & $.19 *$ & -.04 & .13 & .01 & $.26 * * *$ & $.81 * * *$ & $.56 * * *$ & $.67^{* * *}$ & - \\
\hline Utilisation of emotion & -.06 & -.03 & .10 & .07 & -.01 & -.12 & $-.16^{*}$ & .00 & -.10 & -.04 & $.67 * * *$ & $.40 * * *$ & $.48 * * *$ & $.41 * * *$ \\
\hline Job performance & $-.35 * * *$ & $.18^{*}$ & $.36 * * *$ & $.30 * * *$ & $.23 * * *$ & .10 & -.06 & -.05 & -.02 & $.18^{* *}$ & .10 & $.15^{*}$ & .04 & .03 \\
\hline Task perfomance & $-.40 * * *$ & $.21 * *$ & $.39 * * *$ & $.33 * * *$ & $.28 * * *$ & .04 & -.10 & -.05 & .07 & .09 & $.15^{*}$ & $.20 * *$ & .04 & .13 \\
\hline OCBI & $.24 * *$ & .13 & $.26 * * *$ & $.23 * * *$ & $-.17 *$ & .13 & -.02 & .12 & .10 & $.23 *$ & .02 & .07 & .01 & .07 \\
\hline OCBO & $-.17 *$ & .13 & $.19 * *$ & .13 & -.08 & .05 & -.18 & -.08 & -.10 & .09 & .03 & .06 & .02 & .05 \\
\hline Extraversion-introversion & -.06 & .00 & -.02 & -.1 & -.05 & -.14 & -.03 & -.00 & $.15^{*}$ & $-.16^{*}$ & -.03 & -.10 & -.00 & -.06 \\
\hline Sensing-intutuion & .06 & .02 & .09 & -.07 & -.06 & -.07 & -.11 & -.12 & .12 & .06 & .02 & -.04 & -.03 & -.05 \\
\hline Thinking-feeling & -.14 & -.10 & -.05 & $-.15 *$ & -.13 & .14 & $.15^{*}$ & .13 & .08 & .01 & .00 & -.06 & .04 & .06 \\
\hline Judging-perceiving & -.11 & -.17 & -.07 & -.11 & -.01 & .12 & $.19 * *$ & .02 & .01 & .12 & .09 & .02 & $.20 * *$ & $.17 *$ \\
\hline Intuition-thinking & $.18^{*}$ & .12 & $.16^{*}$ & .08 & .11 & -.09 & $-.15^{*}$ & -.01 & -.03 & -.01 & -.09 & .03 & -.11 & -.07 \\
\hline Intuition-feeling & $-.19 *$ & -.10 & $-.16 *$ & -.09 & -.14 & $.17 *$ & $.21 * *$ & .13 & .08 & .03 & $.15 *$ & $-.17^{*}$ & -.13 & -.11 \\
\hline Sensing-thinking & $.18^{*}$ & .13 & $.16^{*}$ & .09 & .13 & $-.16 *$ & $-.17 *$ & $-.15^{*}$ & -.01 & -.02 & .05 & .07 & .07 & -.02 \\
\hline Sensing- feeling & $-.18^{*}$ & -.06 & -.13 & -.12 & -.14 & $.18^{*}$ & $.21 * *$ & .08 & .12 & .04 & .09 & -.02 & .11 & .09 \\
\hline
\end{tabular}

WEIS, Wong's Emotional Intelligence Scale; AES, Assessing Emotions Scale; GAMA, General Ability Measure for Adults; OCBI, organisation citizenship behaviour directed towards other individuals; OCBO, organisation citizenship behaviour directed towards the organisation;

Note: ${ }^{* *} p \leq 0.001 ; * * p \leq 0.01 ;{ }^{*} p<0.05$. 
TABLE 4 (Continues...): Bivariate correlations of the dependent and predictor variables.

\begin{tabular}{|c|c|c|c|c|c|c|c|c|c|c|c|c|c|}
\hline Variable & $\begin{array}{c}\text { Utilisation } \\
\text { of } \\
\text { emotion }\end{array}$ & $\begin{array}{l}\text { Job } \\
\text { performance }\end{array}$ & $\begin{array}{c}\text { Task } \\
\text { perfomance }\end{array}$ & OCBI & ОСвО & $\begin{array}{l}\text { Extraversion- } \\
\text { introversion }\end{array}$ & $\begin{array}{l}\text { Sensing- } \\
\text { intutuion }\end{array}$ & $\begin{array}{l}\text { Thinking- } \\
\text { feeling }\end{array}$ & $\begin{array}{l}\text { Judging- } \\
\text { perceiving }\end{array}$ & $\begin{array}{l}\text { Intuition- } \\
\text { thinking }\end{array}$ & $\begin{array}{l}\text { Intuition- } \\
\text { feeling }\end{array}$ & $\begin{array}{l}\text { Sensing- } \\
\text { thinking }\end{array}$ & $\begin{array}{l}\text { Sensing- } \\
\text { feeling }\end{array}$ \\
\hline GAMA & - & - & - & - & - & - & - & - & - & - & - & - & - \\
\hline Matching & - & - & - & - & - & - & - & - & - & - & - & - & - \\
\hline Analogies & - & - & - & - & - & - & - & - & - & - & - & - & - \\
\hline Sequence & - & - & - & - & - & - & - & - & - & - & - & - & - \\
\hline Construction & - & - & - & - & - & - & - & - & - & - & - & - & - \\
\hline $\begin{array}{l}\text { Self emotional } \\
\text { appraisal }\end{array}$ & - & - & - & - & - & - & - & - & - & - & - & - & - \\
\hline $\begin{array}{l}\text { Others motional } \\
\text { appraisal }\end{array}$ & - & - & - & - & - & - & - & - & - & - & - & - & - \\
\hline Use of emotion & - & - & - & - & - & - & - & - & - & - & - & - & - \\
\hline Regulation of emotion & - & - & - & - & - & - & - & - & - & - & - & - & - \\
\hline AES & - & - & - & - & - & - & - & - & - & - & - & - & - \\
\hline $\begin{array}{l}\text { Managing own } \\
\text { emotion }\end{array}$ & - & - & - & - & - & - & - & - & - & - & - & - & - \\
\hline $\begin{array}{l}\text { Managing others } \\
\text { emotion }\end{array}$ & - & - & - & - & - & - & - & - & - & - & - & - & - \\
\hline Utilisation of emotion & - & - & - & - & - & - & - & - & - & - & - & - & - \\
\hline Job performance & -.03 & - & - & - & - & - & - & - & - & - & - & - & - \\
\hline Task perfomance & -.09 & $.79 * * *$ & - & - & - & - & - & - & - & - & - & - & - \\
\hline OCBI & -.08 & $.79 * * *$ & $.40 * * *$ & - & - & - & - & - & - & - & - & - & - \\
\hline ОСВО & -.06 & $.75 * * *$ & $.43 * * *$ & $.48 * * *$ & - & - & - & - & - & - & - & - & - \\
\hline $\begin{array}{l}\text { Extraversion- } \\
\text { introversion }\end{array}$ & .08 & -.08 & -.14 & -.00 & $-.03-$ & - & - & - & - & - & - & - & - \\
\hline Sensing-intutuion & -.01 & .11 & .11 & .06 & .07 & -.00 & - & - & - & - & - & - & - \\
\hline Thinking-feeling & -.00 & -.13 & -.04 & -.13 & -.14 & -.07 & -.03 & - & - & - & - & - & - \\
\hline Judging-perceiving & -.02 & .01 & -.02 & .06 & -.11 & .13 & .05 & $.11-$ & - & - & - & - & - \\
\hline Intuition-thinking & -.11 & .08 & -.02 & -.04 & .13 & -.01 & -.14 & $-.54 * * *$ & $-.02-$ & - & - & - & - \\
\hline Sensing- feeling & -.09 & -.10 & .01 & -.05 & $-.15^{*}$ & .00 & .13 & $.62 * * *$ & .08 & $-.87 * * *$ & $.28 * * *$ & $-.34 * * *$ & - \\
\hline
\end{tabular}

TABLE 5: Model fit statistics: Structural equation models.

\begin{tabular}{|c|c|c|c|c|c|c|c|}
\hline Model & Variables & Chi-square & $d f$ & $P$ & RMSEA & SRMR & CFI \\
\hline 1 & $\begin{array}{l}\text { Cognitive intelligence, ability emotional intelligence, trait emotional } \\
\text { intelligence, and personality type }\end{array}$ & 318.99 & 253 & $<0.0001$ & 0.05 & 0.07 & 0.92 \\
\hline 2 & $\begin{array}{l}\text { Cognitive intelligence, ability emotional intelligence, and trait emotional } \\
\text { intelligence. }\end{array}$ & 156.95 & 84 & $<0.0001$ & 0.05 & 0.05 & 0.94 \\
\hline 3 & Ability emotional intelligence and trait emotional intelligence. & 85.09 & 41 & $<0.0001$ & 0.06 & 0.06 & 0.93 \\
\hline 4 & Ability emotional intelligence, trait emotional intelligence, and personality type & 216.4 & 139 & $<0.0001$ & 0.06 & 0.07 & 0.93 \\
\hline
\end{tabular}

SRMR, standardised root mean residual; CFI, comparative fit index; RMSEA, root means square error of approximation; df, degrees of freedom.

because the RMSEA and SRMR were below 0.08, and the CFI was above 0.90 .

Table 6 shows the various path analyses for the four SEM models using the latent variables. Practical effect sizes were reported in line with Cohen et al. (2013), and the pathways were all positive. For SEM Prediction Model 1, only CI (GAMA) $\left(\beta=0.80 ; R^{2}=0.65\right.$; large practical effect, $\left.p \leq 0.001\right)$, ability EI (WEIS) $\left(\beta=0.64 ; R^{2}=0.41\right.$; large practical effect, $p \leq 0.001)$ and personality (MBTI) $\left(\beta=0.22 ; R^{2}=0.05\right.$; small practical effect, $p \leq 0.05$ ) loaded significantly onto job performance. Concerning SEM prediction model 2, only CI (GAMA) $\left(\beta=0.73 ; R^{2}=0.54 ;\right.$ large practical effect, $\left.p \leq 0.001\right)$ and ability EI (WEIS) ( $\beta=0.32 ; R^{2}=0.10$; small practical effect, $p \leq 0.01$ ) loaded significantly onto the job performance criterion. Structural equation modelling prediction model 3 shows that both types of EI did not load significantly onto job performance. In SEM prediction model 4, only personality type $\left(\beta=0.24 ; R^{2}=0.06\right.$; small practical effect, $p \leq 0.05)$ loaded significantly onto the job performance variable. The results show that CI was the best predictor of job performance, followed by ability EI, and then by personality. Trait EI did not account for variance in job performance.

The next step was to ascertain the best fit final SEM model, and this was achieved by computing the chi-square comparisons tests. Table 5 shows that the fit statistics of model 1 and model 2 were relatively better than those of model 3 and model 4 . The results showed that SEM prediction models 1 and 2 contained the majority of the predictor variables and had the highest variance in job performance explained by the predictor variables compared with models 
TABLE 6: Path analysis of the structural equation modelling prediction models.

\begin{tabular}{llllllc}
\hline Scale & Predictor/IV & Criterion/DV & $\boldsymbol{\beta}$ & $\boldsymbol{R}^{2}$ & Standard error & $\boldsymbol{t}$ \\
\hline SEM prediction model 1 & & & & & \\
GAMA & CI & JP & 0.80 & 0.65 & 0.20 & $4.03^{* *}$ \\
WEIS & Ability EI & JP & 0.64 & 0.41 & 0.24 & $2.66^{* *}$ \\
AES & Trait EI & JP & 0.00 & 0.00 & 0.11 & 0.02 \\
MBTI $\quad$ Personality & JP & 0.22 & 0.05 & 0.11 & $1.97^{*}$ \\
SEM prediction model 2 & & & & & \\
GAMA & CI & JP & 0.73 & 0.54 & 0.07 & $9.89^{* * *}$ \\
WEIS $\quad$ Ability EI & JP & 0.32 & 0.10 & 0.10 & $3.25^{* *}$ \\
AES $\quad$ Trait EI & JP & -0.03 & 0.00 & 0.08 & -0.40 \\
SEM prediction model 3 & & & & & \\
WEIS $\quad$ Ability EI & JP & 0.07 & 0.00 & 0.09 & 0.74 \\
AES $\quad$ Trait EI & JP & 0.00 & 0.00 & 0.08 & -0.02 \\
SEM prediction model 4 & & & & & \\
WEIS & Ability EI & JP & 0.19 & 0.04 & 0.14 & 1.37 \\
AES $\quad$ Trait EI & JP & 0.05 & 0.00 & 0.10 & 0.52 \\
MBTI $\quad$ Personality & JP & 0.24 & 0.06 & 0.10 & $2.42^{*}$
\end{tabular}

$\mathrm{JP}$, job performance; WEIS, Wong's emotional intelligence Scale; AES, assessing emotion scale; GAMA, General Ability Measure for Adults; MBTh, Myers-Brigs, Type Indicator; SEM, scale, GAMA, Genal Abilty Measure for Adults; MBTI, Myers-Briggs Type Indicator, SEM

Notes: $N=299 ;{ }^{* * *} p \leq 0.001{ }^{* *} p \leq 0.01{ }^{*} p<0.05$; practical effect: $R^{2} \geq 0.02$ (small effect size), $R^{2} \geq 0.13$ (moderate effect size), $R^{2} \geq 0.26$ (large effect size); $t>2.56(p \leq 0.01)^{* *} ; t>$ $1.96(p \leq 0.05)^{*}$

3 and 4 . Thus, the chi-square comparison test was only performed for models 1 and 2 as illustrated in Table 7 .

Table 7 shows that model 1 and model $2(p=0.64)$ were not significantly different, indicating that both models had relatively equal strengths in predicting job performance. However, choosing model 2 (with three predictor variables) ahead of model 1 (with all the four predictor variables) would result in reduction of the predictive power. This is because the incremental validity of $11 \%(65 \%-54 \%)$ from CI, $31 \%$ $(41 \%-10 \%)$ from ability EI and 5\% (absent in model 2) from personality would be lost. Thus, we chose model 1 as the final SEM prediction model for the study. Figure 1 illustrates SEM model 1. In summary, the results provided partial evidence in support of the research hypothesis.

\section{Discussion}

This research sought to propose an empirically valid personnel selection model for the Zimbabwean context. The proposed selection model encompassed the influence of predictor variables, which included CI, ability EI, trait EI and the MBTI personality types on job performance. The results showed that trait EI could not significantly predict job performance when combined with $\mathrm{CI}$, ability EI and the MBTI personality types. However, CI significantly predicted job performance (large practical effect), followed by ability EI (large practical effect) and then by personality types (small practical effect). The prominence of $\mathrm{CI}$ as the best predictor of job performance is in line with earlier research (Schmidt \& Hunter, 2004) and extensive meta-analyses performed in the past decade (Joseph \& Newman, 2010, O’Boyle at al., 2011).

From a selection predictive point of view, the criteria for a personnel selection model was not fully met because trait EI could not account for any variance in job performance. It is
TABLE 7: Chi-square comparison: Model 1 and model 2.

\begin{tabular}{lcccc}
\hline Variable & Model $\mathbf{1}$ & Model 2 & Diff. & $\boldsymbol{p}$ \\
\hline Chi-square & 318.99 & 156.95 & 162.04 & 0.64 \\
$D f$ & 253.00 & 84.00 & 169.00 & - \\
\hline
\end{tabular}

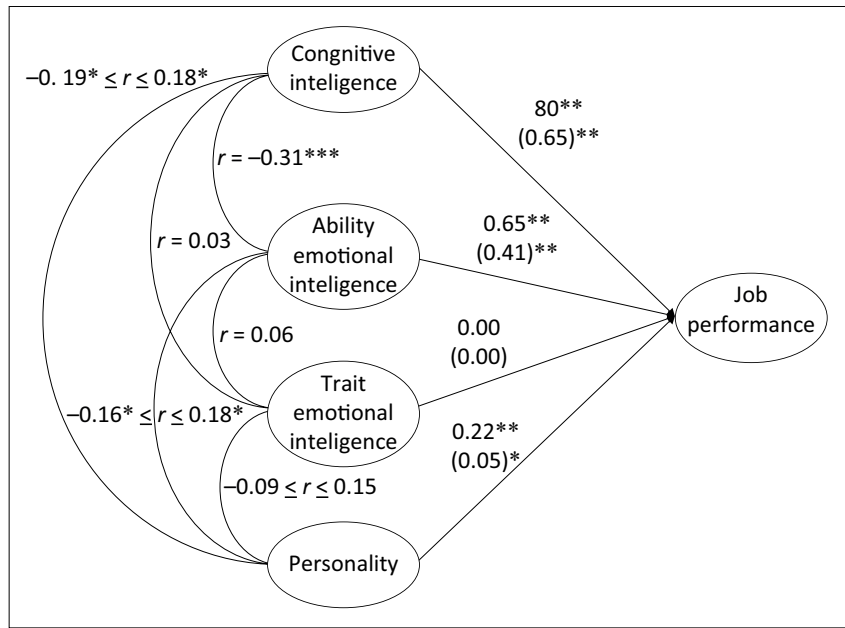

FIGURE 1: The final structural equation modelling prediction model: Model 1. Note: $* * * p \leq 0.001 ; * * p \leq 0.01 ;{ }^{*} p<0.05$.

interesting to note that when paired alone, ability EI and trait EI were not significant predictors of job performance, suggesting that on their own, the trait EI and ability EI may not significantly predict job performance. However, ability EI could still be useful because it became a significant predictor of job performance when paired with CI. This is because when CI and ability EI are paired, organisations may be able to tap other emotional competencies important in predicting job performance. The outcome where personality types consistently predicted job performance with small practical effect corroborates past research where the personality types were not a strong predictor, but rather a useful personnel development tool (Leary et al., 2009; Sample, 2017; Varvel, Adams, Pridie, \& Ulloa, 2004). Thus, the research partially provided supportive evidence for the research hypothesis.

\section{Theoretical and managerial implications}

The extensive review of the literature in a quest to hypothesise a theoretical personnel selection model to compare with the empirically manifested model contributed to the theory building. Although personnel selection theory has been extended through combining results from different studies conducted previously in different settings or through metaanalyses (Joseph \& Newman, 2010; O'Boyle et al., 2011), the present study offers an empirical approach to theory building through the simultaneous investigation of the predictive power of the predictor variables. The present research may be the first of its kind in Zimbabwe and in personnel selection research, where the influence of CI, EI (ability and trait) and personality type on job performance has been investigated in a single study. The proposed personnel selection model 
contributed to theory building and provides the basis for future research.

The study presents a number of managerial implications for organisations in Zimbabwe and beyond. Measures of $\mathrm{CI}$ should form a significant part of personnel selection models because $\mathrm{CI}$ was found to explain the highest variance in job performance with large practical effect, confirming its pervasiveness in predicting job performance across most, if not all, occupations (Joseph \& Newman, 2010; O'Boyle et al., 2011). Although ability EI may not predict job performance on its own, it is useful in the assessment of emotional and noncognitive antecedents of job performance provided that it is paired with CI. The fact that personality types had a small practical effect in predicting job performance indicates that they may not be a strong predictor of job performance per se. Rather HR practitioners should consider using personality type assessments in selection to identify personnel development needs or person-job fit. The development needs ought to be identified at the personnel selection stage to ensure the closest person-job fit and to achieve savings in investment in individual personnel development interventions, postselection. Although trait EI could not account for the variance in job performance, it could still be used to assess emotional competences such as decision-making, group functioning and interpersonal relations because overall trait EI was positively correlated with task performance and perception of emotion was positively correlated with task performance and overall job performance.

The use of multi-criteria personnel selection and job performance measures has further managerial implications. For the present study, all the predictor variables and the criterion of job performance consisted of the overall scales and subscales to provide insight into the relationships between the overall predictor variable scales and subscales, and the job performance criteria and its subscales are in line with Ployhart and Schneider (2012). For example, it may be interesting to note that CI correlates more closely with task performance than contextual performance (OCBI and OCBO), something that should guide HR practitioners. Organisations should therefore be guided accordingly in choosing personnel selection measures that are most appropriate to the relevant job performance criteria.

\section{Limitations and recommendations for future research}

Although the study offers theoretical and practical implications, the research had some limitations which should be considered as areas of improvement for future research. For example, the sample size for the present study was $N=$ 299 and consisted of only supervisory staff, and professionally qualified and experienced specialists. Future research should include larger sample sizes and a wide range of occupational levels for improved validity generalisation. Because the present study was cross-sectional by design (Leavy, 2017; Teasdale \& Ivanich, 2017), future research may consider adopting longitudinal studies to gain more understanding of the behaviour of variables across life spans and cause-effect associations. Where possible, future research could also use latent class analysis to develop profiles of high performers.

\section{Conclusion}

The study enhanced personnel selection theory by identifying predictor variables that best predict job performance. Although HR practitioners in Zimbabwe and beyond could adopt the proposed personnel selection model, the research findings provided preliminary evidence of the utility of CI, ability EI, trait EI and personality, paving way for more research the area.

\section{Acknowledgements}

\section{Competing interests}

The authors have declared that no competing interests exist.

\section{Authors' contributions}

All the authors contributed equally to this work.

\section{Funding information}

This research received no specific grant from any funding agency in the public, commercial or not-for-profit sectors.

\section{Data availability statement}

Data sharing is not applicable to this article as no new data were created or analysed in this study.

\section{Disclaimer}

The views and opinions expressed in this article are those of the authors and do not necessarily reflect the official policy or position of any affiliated agency of the authors.

\section{References}

Abraham, R. (2004). Emotional competence as antecedent to performance: A contingent framework. Genetics, Social, and General Psychology Monographs, 130(2), 117-143. https://doi.org/10.3200/MONO.130.2.117-145

Afshari, A.R., Nikolić, M. \& Ćoćkalo, D. (2014). Applications of fuzzy decision-making for personnel selection problem: A review. Journal of Engineering Management and Competitiveness (JEMC), 4(2), 68-77. https://doi.org/10.5937/jemc1402068A

AlDosirya, K.S., Alkhadher, O.H., AlAqraa, E.M., \& Anderson, N. (2016). Relationships between emotional intelligence and sales performance in Kuwait. Journal of Work and Organizational Psychology, 32, 39-45. https://doi.org/10.1016/j. rpto.2015.09.002

Anastasi, A., \& Urbina, S. (1997). Psychological testing. Upper Saddle River, NJ: Prentice-Hall International.

Austin, E.J. (2010). Measurement of ability emotional intelligence: Results for two new tests. British Journal of Psychology, 101, 563-578. https://doi. org/10.1348/000712609X474370

Austin, E.J. Farrelly, D., Black, C. \& Moore H. (2007). Emotional intelligence, Machiavellianism and emotional manipulation: Does EI have a dark side? Personality and Individual Differences, 43, 179-189. https://doi.org/10.1016/j. paid.2006.11.019

Bastian, V.A., Bums, N.R., \& Nettelbeck, T. (2005). Emotional intelligence predicts life skills, but not as well as personality and cognitive abilities. Personality and Individual Differences, 39, 1135-1145. https://doi.org/10.1016/j.paid.2005.04.006 
Borman, W.C., \& Motowidlo, S.J. (1993). Expanding the criterion domain to include elements of contextual performance. In N. Schmitt \& W.C. Borman (Eds.) elements of contextual performance. In N. Schmitt \& W.C. Borman (Eds.),
Personnel selection in organizations (pp. 71-98). San Francisco, CA: Jossey-Bass.

Bozionelos, N., \& Singh, S.K. (2017). The relationship of emotional intelligence with task and contextual performance: More than it meets the linear eye. Personality and Individual Differences, 116, 206-211. https://doi.org/10.1016/j. paid.2017.04.059

Brackett, M., \& Mayer, J.D. (2003). Convergent, discriminant, and incremental validity of competing measures of emotional intelligence. Personality and Social Psychology Bulletin, 29, 1147-1158. https://doi.org/10.1177/0146167203254596

Burger, J.M. (2014). Personality (9th edn.). Stamford, CT: Cengage Learning.

Caldwell, C., Beverage, M., \& Converse, P. (2018). Selecting for flair factors: Improving the selection process. Business and Management Research, 7(1), 1-10. https:// doi.org/10.5430/bmr.v7n1p1

Carr, G.G.P.E., De La Garza, J.M., \& Vorster, M.C (2002). Relationship between personality traits and performance for engineering and architectural professionals providing design services. Journal of Management in Engineering, 18(4), 158-166. https://doi.org/10.1061/(ASCE)0742-597X(2002)18:4(158)

Cattell, R.B. (1941). Some theoretical issues in adult intelligence testing. Psychological Bulletin, 38, 592-597.

Cattell, R.B. (1971). Abilities: Their structure, growth, and action. Boston, MA Houghton Mifflin.

Chen, J., Tian, J.Q., Miao, D., \& Chia, R.C. (2009). Item description in translated tests: Cultural effects on factor structure of the Chinese version of the Myers-Brigg Type Indicator-G. Social Behavior and Personality, 37(1), 31-40. https://doi. org/10.2224/sbp.2009.37.1.31

Cohen, J., Cohen, P., West, S.G., \& Aiken, L.S. (2013). Applied multiple regression/ correlation analysis for the behavioral sciences. New York, NY: Routledge.

Costa, D., Van, C., Abbott, P., \& Krass, I. (2015). Investigating general practitioner engagement with pharmacists in home medicines review. Journal of Interprofessional Care, 1, 1-7. https://doi.org/10.3109/13561820.2015.1012253

Costa, P.T., \& McCrae, R.R. (1992). NEO-PI-R: Professional manual. Odessa, FL: Psychological Assessment Resources.

Cote, S., \& Miners C.T.H. (2006). Emotional intelligence, cognitive intelligence and job performance. Administrative Science Quarterly, 51, 1-28. https://doi. org/10.2189/asqu.51.1.1

Dale, M. (2003). A manager's guide to recruitment \& selection (2nd edn.). London: Kogan Page.

Dan, P., Zhang, Y., \& Li, Z. (2015). Predictive capability of cognitive ability and cognitive style for spaceflight emergency operation performance. International Journal of Industrial Ergonomics, 54, 48-56. https://doi.org/10.1016/j.ergon.2016.04.008

Davis, A.S., Bardos, A.N., \& Woodward, K.M. (2006). Concurrent validity of the general ability measure for adults (GAMA) with sudden-onset neurological impairment. International Journal of Neuroscience, 116(10), 1215-1221. https:// doi.org/10.1080/00207450500516511

Dumbu, E., \& Chadamoyo, P. (2012). Managerial deficiencies in the small and medium enterprises (SMEs) in the craft industry: An empirical evidence of SMEs at Great Zimbabwe in Chief Mugabe's area. European Journal of Business and Management, 4(10), 28-35.

Fallon, C.K., Jaafar, A.R., Panganiban, A.R., Wohleber, R., Matthews, G., Kustubayeva, A.M., \& Roberts, R. (2014). Emotional intelligence, cognitive ability and information search in tactical decision-making. Personality and Individual Differences, 65, 24-29. https://doi.org/10.1016/j.paid.2014.01.029

Feist, J., \& Feist, G.J. (2009). Theories of personality (7th edn.). New York, NY: McGrawHill.

Floyd, R.G., McGrew, K.S., Barry, A., Rafael, F., \& Rogers, J. (2009). General and specific effects on Cattell-Horn-Carroll broad ability composites: Analysis of the Woodcock-Johnson III normative update Cattell-Horn-Carroll factor clusters across development. School Psychology Review, 38(2), 249-265.

Foo, M.D., Elfenbein, H.A., Tan, H.H., \& Aik, V.C. (2004). Emotional intelligence and negotiation: The tension between creating and claiming value. Internationa Journal of Conflict Management, 15(4), 411-429. https://doi.org/10.1108/ eb022920

Furnham, A., Dissou, G., Sloan, P., \& Chamorro-Premuzic, T. (2007). Personality and intelligence in business people: A study of two personality and two intelligence measures. Journal of Business Psychology, 22, 99-109. https://doi.org/10.1007/ s10869-007-9051-z

Gardner, H. (1983). Frames of mind: The theory of multiple intelligences. New York, NY: Basic Books.

Gardner, H. (1993). Multiple intelligences: The theory in practice. New York, NY: Basic Books.

Gardner, H. (1999). Intelligence reframed: Multiple intelligences for the 21st century. New York, NY: Basic Books.

Gatewood, R., Feild, H.S., \& Barrick, M. (2016). Human resource selection (8th edn.) Boston, MA: Cengage Learning.

Goldenberg, I., Matheson, K., \& Mantler, J. (2006). The assessment of emotional intelligence: A comparison of performance-based and self-report methodologies. Journal of Personality Assessment, 86(1), 33-45. https://doi.org/10.1207/ Journal of Personality
s15327752jpa8601_05

Gooty, J., Gavin, M.B., Ashkanasy, M.N., \& Thomas, J.S. (2014). The wisdom of letting go and performance: The moderating role of emotional intelligence and discrete emotion. Journal of Occupational and Organizational Psychology, 87, 392-413. https://doi.org/10.1111/joop.12053
Gottfredson, L.S. (1997). Why g matters: The complexity of everyday life. Intelligence, 24, 79-132. https://doi.org/10.1016/S0160-2896(97)90014-3

Greenidge, D., Devonish, D., \& Alleyne, P. (2014). The relationship between abilitybased emotional intelligence and contextual performance and counterproductive work behaviors: A test of the mediating effects of job satisfaction. Human Performance, 27, 225-242. https:/doi.org/10.1080/08959285.2014.913591

Gregory, R.J. (2004). Psychological testing: History, principles, and applications. New Delhi: Pearson Education.

Guilford, J.P. (1967). The nature of human intelligence. New York, NY: McGraw-Hill.

Hattrup, K. (2012). Using composite predictors in personnel selection. In N. Schmitt (Ed.), The Oxford handbook of personnel assessment and selection (pp. 297-322). New York, NY: Oxford University Press.

Higgs, M. (2001). Is there a relationship between the Myers-Briggs type indicato and emotional intelligence? Journal of Managerial Psychology, 16(7), 509-533. https://doi.org/10.1108/EUM0000000006165

Hui-Hua, Z., \& Schutte, N.S. (2015). Personality, emotional intelligence and otherrated task performance. Personality and Individual Differences, 87, 298-301 https:/doi.org/10.1016/j.paid.2015.08.013

Hunter, J.E., \& Hunter, R.F. (1984). Validity and utility of alternative predictors of job performance. Psychological Bulletin, 96(1), 72-98. http://doi.org/10.1037/0033 2909.96.1.72

Husina, W.N.I., Santos, A., Ramosa, H.M., \& Nordinb, M.S. (2013). The place of emotional intelligence in the 'intelligence' taxonomy: Crystallized intelligence or fluid intelligence factor? Social and Behavioural Sciences, 97, 214-223. https:// doi.org/10.1016/j.sbspro.2013.10.225

IBM. (2013). SPSS Statistics for Windows, version 22. Armonk NY: IBM Corp.

Jensen, A.R. (1998). The $g$ factor: The science of mental ability. London: Praeger.

Jiao, C., \& Hardie, T. (2009). Nationality, cultural values and the relative importance of task performance and organizational citizenship behaviour in performance evaluation decisions. Journal of Comparative International Management, 12(1), 17-28.

Johnson, D.A., \& Miller, J. (2003). Emotional Intelligence: Construct validity findings from the Global Personality Inventory. Paper submitted for presentation at the from the Global Personality Inventory. Paper submitted for presentation at the
2003 annual conference of the Society for Industrial and Organizational Psychology.

Joseph, D.L., \& Newman, D.A. (2010). Emotional intelligence: An integrative metaanalysis and cascading model. Journal of Applied Psychology, 95(1), 54-78. https://doi.org/10.1037/a0017286

Jundt, D.K., Shoss, M., \& Huang, J.L. (2014). Individual adaptive performance in organizations: A review. Journal of Organizational Behavior, 36(S1), S53-S71. https:/doi.org/10.1002/job.1955

Jung, C.G. (1921). Psychological types. Princeton, NJ: Princeton University Press.

Kaluginaa, E., \& Shvyduna, S. (2014). An effective personnel selection model. Procedia Computer Science, 31, 1102-1106. https://doi.org/10.1016/j.procs.2014.05.365

Kaufman, A., McLean, J., \& Lincoln, A. (1996). The relationship of the Myers-Briggs type indicator (MBTI) to IQ level and the fluid and crystallized IQ discrepancy on the Kaufman Adolescent and Adult Intelligence Test (KAIT). Assessment, 3, 225239. https://doi.org/10.1177/1073191196003003004

Kirby, L., \& Myers, K. (2000). Introduction to type. Oxford: Oxford Psychological Press.

Lam, T., \& Kirby, S.L. (2002). Is emotional intelligence and advantage? An exploration of the impact of emotional and general intelligence on individua performance. Journal of Social Psychology, 142(1), 133-143. https://doi. org/10.1080/00224540209603891

Leary, M.M., Reilly, M.D., \& Brown, F.W. (2009). A study of personality preferences and emotional intelligence. Leadership \& Organization Development Journal, 30(5), 421-434. https://doi.org/10.1108/01437730910968697

Leavy, P. (2017). Research design: Quantitative, qualitative, mixed methods, artsbased, and community-based participatory research approaches. New York, NY: The Guilford Press.

Matula, P., \& Uon, V. (2016). A causal relationship model work engagement affecting organizational citizenship behavior and job performance of professional nursing. Middle-East Journal of Scientific Research, 24(5), 1600-1605.

Mayer, J.D., \& Salovey, P. (1997). What is emotional intelligence? In P. Salovey \& D. Sluyter (Eds.), Emotional development and emotional intelligence: Educationa implications (pp. 3-31). New York, NY: Basic Books.

Mayer, J.D., Salovey, P., \& Caruso, D.R. (2000). Models of emotional intelligence. In R. Sternberg (Ed.), Handbook of intelligence (pp. 396-420). New York, NY: Cambridge University Press.

Mayer, J.D., Salovey, P., \& Caruso, D.R. (2002). Manual for the MSCEIT Mayer-SaloveyCaruso Emotional Intelligence Test. Toronto: Multi-Health Systems.

Mayer, J.D., Salovey, P., \& Caruso, D.R. (2004). Emotional Intelligence: Theory, findings and implications. Psychological Inquiry, 15(3), 197-215. https://doi.org/10.1207/ s15327965pli1503_02

McCaulley, M.H., \& Martin, C.R. (1985). Career assessment and the Myers-Briggs Type Indicator. Journal of Career Assessment, 3(2), 219-239. https://doi. org/10.1177/106907279500300208

McNulty, J.P., Mackay, S.J., Lewis, S.J., Lane, S., \& White, P. (2016). An international study of emotional intelligence in first year radiography students: The relationship to age, gender and culture. Radiography, 22, 171-176. https://doi.org/10.1016/j. to age, gender and

Miao, C., Humphrey, R.H., \& Qian, S. (2017). Are the emotionally intelligent good citizens or counterproductive? A meta-analysis of emotional intelligence and its relationships with organizational citizenship behavior and counterproductive work behaviour. Personality and Individual Differences, 116, 144-156. https://doi. org/10.1016/j.paid.2017.04.015 
Mikolajczak, M., Roy, E., Verstrynge, V., \& Luminet, O. (2009). An exploration of the moderating effect of trait emotional intelligence on memory and attention in neutral and stressful conditions. British Journal of Psychology, 100, 699-715. https://doi.org/10.1348/000712608X395522

Motowidlo, S.J. (2003). Job performance. In W.C. Borman, D.R. Ilgen, R.J. Klimoski \& B.I. Weiner (Eds.), Handbook of psychology, vol. 12: Industrial and organisational psychology (pp. 39-53). Hoboken, NJ: Wiley.

Murphy, A., \& Janeke, H.C. (2010). The relationship between thinking styles and emotional intelligence: An exploratory study. South African Journal of Psychology, 39(3), 357-375. https://doi.org/10.1177/008124630903900310

Myers, I.B. (1987). Introduction to type. Palo Alto, CA: Consulting Psychologists Press.

Myers, I.B., \& McCaulley, M. (1985). Manual: A guide to the development and use of the Myers-Briggs Type Indicator. Palo Alto, CA: Consulting Psychologists.

Myers, I.B., McCaulley, M.H., Quenk, N.L., \& Hammer, A.L. (1998). MBTI Manual: A guide to the development and use of the Myers-Briggs Type Indicator (3rd edn.). Palo Alto, CA: Consulting Psychologists Press.

Myers, P.B., \& Myers, K.D. (2009). MBT/ ${ }^{\circledR}$ form M manual supplement. Mountain View, CA: CPP.

Naglieri, J.A., \& Bardos, A.N. (1997). GAMA (General Ability Measure for Adults) manual. Minneapolis, MN: NCS Pearson.

Nguwi, M. (2010, August 13). Psychometric testing: Guide to good practice. The Financial Gazette. Retrieved from http://www.financialgazette.co.zw/ comment/5109-psychometric-testing-guide-to-good-practice.html

Nguwi, M. (2014a, November 12). Best practice in selecting graduate trainees. The Financial Gazette. Retrieved from http://www.financialgazette.co.zw/bestpractice-in-selecting-graduate-trainees/

Nguwi, M. (2014b, November 12). Best practice in recruitment, selection. The Financial Gazette. Retrieved from http://www.financialgazette.co.zw/bestpractice-in-recruitment-selection/

Nyamubarwa, W., Mupani, H., \& Chiduuro, C. (2013). An analysis of the human resource practices in the mining industry in Zimbabwe's Midlands province: A relook at the resource-based view of managing human resources. IOSR Journa of Humanities and Social Science, 17(1), 16-123. https://doi.org/10.9790/0837 171116123

O’Boyle, E., Humphrey, R.H., Pollack, J.M., Hawver, T.H., \& Story, P. (2011). The relation between emotional intelligence and job performance: A meta-analysis. Journal of Organizational Behavior, 32, 788-818. https://doi.org/10.1002/job.714

Organ, D.W., Podsakoff, P.M., \& MacKenzie, S.B. (2006). Organizational citizenship behavior: Its nature, antecedents, and consequences. New Delhi: Sage.

Perry, C., \& Ball, I. (2005). Emotional intelligence and teaching: Further validation evidence. Issues in Educational Research, 15(2), 175-192.

Petrides, K.V., \& Furnham, A. (2003). Trait emotional intelligence: Behavioura validation in two studies of emotion recognition and reactivity to mood induction. European Journal of Personality, 17, 39-57. https://doi.org/10.1002/per.466

Petrides, K.V., Pita, R., \& Kokkinaki, F. (2007). The location of trait emotional intelligence in personality factor space. British Journal of Psychology, 98, 273-289. https://doi.org/10.1348/000712606X120618

Ployhart, R.E., \& Schneider, B. (2012). The social and organizational context of personnel selection. In N. Schmitt (Ed.), The Oxford handbook of personnel assessment and selection (pp. 48-61). New York, NY: Oxford University Press.

Prince, A.L. (2015). Examining the relationship between leadership decision making styles and personality type within the department of defence. Unpublished doctoral dissertation. Norfolk, VA: Old Dominion University.

Rashid, M.M., Mondol, M.A.S., Rahman, M.S., \& Noman, M.R.F. (2016). Use of communication sources by the women beneficiaries of RDRS in income generating activities. International Journal of Agricultural Extension, 3(3), 187-194.

Rich, B.L., Lepine, J.A., \& Crawford, E.R. (2010). Job engagement: Antecedents and effects on job performance. Academy of Management Journal, 53(3), 617-635. https://doi.org/10.5465/AMJ.2010.51468988

Rindermann, H. (2007). The big g-factor of national cognitive ability. European Journal of Personality, 21, 767-787. https://doi.org/10.1002/per.658

Sample, J. (2017). A review of the Myers-Briggs Type Indicator in public affairs education. Journal of Public Affairs Education, 23(4), 979-992. https://doi.org/10 $.1080 / 15236803.2017 .12002300$

SAS. (2013). Statistical Analysis System, version 9.4. Cary, NC: SAS Institute Inc.

Schmidt, F.L., \& Hunter, J.E. (1998). The validity and utility of selection methods in personnel psychology: Practical and theoretical implications of 85 years of research findings. Psychological Bulletin, 124, 262-274. https://doi.org/10.1037/00332909.124.2.262

Schmidt, F.L., \& Hunter, J.E. (2004). General mental ability in the world of work: Occupational attainment and job performance. Journal of Personality and Socia Psychology, 86(1), 162-173. https://doi.org/10.1037/0022-3514.86.1.162

Schmit, M.J., Kihm, J.A., \& Robie, C. (2000). Development of a global measure of personality. Personnel Psychology, 53(1), 153-193. https://doi.org/10.1111/j.1744-6570.2000. tb00198.x

Schutte, N.S., Malouff, J.M., \& Bhullar, N. (2009). The assessing emotions scale. In C. Stough, D. Saklofske \& J. Parker (Eds.), The assessment of emotional intelligence (pp. 119-135). New York, NY: Springer.
Schutte, N.S., Malouff, J.M., Hall, L.E., Haggerty, D.J., Cooper, J.T., Golden, C.J., \& Dornheim, L. (1998). Development and validation of a measure of emotional intelligence. Personality and Individual Differences, 25, 167-177. https://doi. org/10.1016/S0191-8869(98)00001-4

Shehu, M.A., \& Saeed, F. (2016). An adaptive personnel selection model for recruitment using domain-driven data mining. Journal of Theoretical and Applied Information Technology, 91(1), 117-130.

Sony, M., \& Mekoth, N. (2016). The relationship between emotional intelligence, frontline employee adaptability, job satisfaction and job performance. Journa of Retailing and Consumer Services, 30, 20-32. http://doi.org/10.1016/j. of Retailing and Consur.

Spearman, C. (1904). 'General intelligence', objectively determined and measured. American Journal of Psychology, 15, 201-292. https://doi.org/10.2307/1412107

Spearman, C. (1923). The nature of 'intelligence' and the principles of cognition. London: Macmillan.

Spearman, C. (1927a). 'General intelligence', objectively determined and measured. American Journal of Psychology, 15, 201-293. https://doi.org/10.2307/1412107

Sternberg, R. J. (1985). Beyond IQ: A triarchic theory of intelligence. Cambridge: Cambridge University Press.

Tabachnick, B.G., \& Fidell, L.S. (2001). Using multivariate statistics (4th edn.). Needham Heights, MA: Allyn \& Bacon.

Taber, K.S. (2017). The use of Cronbach's Alpha when developing and reporting research instruments in science education. Research in Science Education, 48, 1-24. https://doi.org/10.1007/s11165-016-9602-2

Teasdale, B., \& Ivanich, J. (2017). Longitudinal methods in substance use research. In J.B. VanGeest, T.P. Johnson \& S.A. Alemagno (Eds.), Research methods in the study of substance abuse. Dordrecht, the Netherlands: Springer.

Tehseen, S., Ramayah, T., \& Sajilan, S. (2017). Testing and Controlling for Common Method Variance: A Review of Available Methods. Journal of Management Sciences, 4(2), 142-168.

Thurstone, L.L. (1938). Primary mental abilities. Chicago, IL: University of Chicago Press.

Tofighi, M., Tirgari, B., Fooladvandi, M., Rasouli, F., \& Jalali, M. (2015). Relationship between emotional intelligence and organizational citizenship behavior in critical and emergency nurses in south-east of Iran. Ethiopian Journal of Health Sciences, 25(1), 79-88. https://doi.org/10.4314/ejhs.v25i1.11

Tufail, M.S., Bashi, M., \& Shoukat, N. (2017). Impact of job design on employee's organizational citizenship behavior and counterproductive work behavior in the banking sector of Faisalabad. City University Research Journal, Special Issue, AIC, Malaysia, 1, 224-235.

Varela, O.E., Salgado, E.I., \& Lasio, M.V. (2010). The meaning of job performance in collectivistic and high power distance cultures. Cross-Cultural Management: An International Journal, 17(4), 407-426. https://doi. org/10.1108/13527601011086603

Varvel, T., Adams, S.G., Pridie, S.J., \& Ulloa, B.C.R. (2004).Team effectiveness and individual Myers-Briggs personality dimensions. Journal of Management in Engineering, 20(4), 141-146. https://doi.org/10.1061/(ASCE)074297X(2004)20:4(141)

Vernon, P.E. (1950). The validation of civil service selection board procedures. Occupational Psychology, 24, 75-95.

Vincent, N., Ward, L., \& Denson, L. (2013). Personality preferences and their relationship to ego development in Australian leadership program participants. Journal of Adult Development, 20, 197-211. https://doi.org/10.1007/s10804-013-9171-9

Virmozelova, N., \& Dimitrova, N. (2013). Relationship between personality types conceptualized by C.G. Jung and emotional intelligence. Psychological Thought, 6(2), 339-357. https://doi.org/10.5964/psyct.v6i2.83

Williams, L., \& Anderson, S. (1991). Job satisfaction and organizational commitment as predictors of organizational citizenship and in-role behaviors. Journal of Management, 17, 601-617. https://doi.org/10.1177/014920639101700305

Willis, O.J., Dumont, R., \& Kaufman, A.S. (2011). Factor analytic models of intelligence. In R.J. Sternberg \& S.B. Kaufman (Eds.), The Cambridge handbook of intelligence (pp. 39-56). Cambridge: Cambridge University Press.

Wolff, S.B., Pescosolido, A.T., \& Druskat, V.U. (2002). Emotional Intelligence as the basis of leadership emergence in self-managing teams. Leadership Quarterly, 13, 505-522. https://doi.org/10.1016/S1048-9843(02)00141-8

Wong, C.S., \& Law, K.S. (2002). The effects of leader and follower emotional intelligence on performance and attitude: An exploratory study. Leadership Quarterly, 13, 243-274. https://doi.org/10.1016/S1048-9843(02)00099-1

Wong, C.S., Law, K.S., \& Wong, P. (2004). Developing and validating of a forced-choice emotional intelligence measure for Chinese respondents in Hong Kong. Asia Pacific Journal of Management, 21, 535-559. https://doi.org/10.1037/0021 9010.89.3.483

Wong, C., Wong, P., \& Law, K.S. (2007). Evidence of the practical utility of Wong's emotional intelligence scale in Hong Kong and mainland China. Asia Pacific Journal of Management, 24, 43-60. https://doi.org/10.1007/s10490-006-9024-1

$\mathrm{Wu}, \mathrm{Y}$. (2011). Job stress and job performance among employees in the Taiwanese finance sector: The role of emotional intelligence. Social Behavior and Personality, 39(1), 21-32. https://doi.org/10.2224/sbp.2011.39.1.21

Zeidner, M., Matthews, G., \& Roberts, R.D. (2004). Emotional Intelligence in the workplace: A critical review. Applied Psychology: An International Review, 53(3), 371-399. https://doi.org/10.1111/j.1464-0597.2004.00176.x

Zinyemba, Z.A. (2014). The challenges of recruitment and selection of employees in Zimbabwean companies. International Journal of Science and Research, 3(1), 29-33. https://doi.org/www.ijsr.net 